\title{
Rappaport, Revisited
}

\begin{abstract}
In Ritual and Religion in the Making of Humanity, Roy Rappaport misses an opportunity to more tightly theorize the synergistic relationship between concepts of the divine, the psyches of ritual participants, and the adaptive dynamics of religious sociality. This paper proposes such a theory by drawing on implicit features of Rappaport's account, fulfilling his goal of a 'cybernetics of the holy.' I argue that concepts of the divine, when made authoritative for participants through ritual, have three important effects: they invite intense and meaningful reconstructions of personal identity according to paradigmatic examples; they act as a form of encoded social memory by organizing human relationship according to a 'spiritual map;' and they provide the cognitive framework that make religious community organization robust, adaptive, and reproductive. We can characterize divine concepts as 'specified absences' that ground each of these effects and link them together in a mutually-reinforcing set.
\end{abstract}

\section{Keywords}

cybernetics; Rappaport; emergence; ritual; decentering; religious experience

\section{Introduction}

Within the field of religious studies, two theoretical works that have had broad, profound impact on the way scholars think about religion have been attempts to think about human sociality from the perspective of emergence theory. These works are Émile Durkheim's The Elementary Forms of Religious Life, and Roy Rappaport's Ritual and Religion in the Making of Humanity. ${ }^{1}$ Hart (1999) and Lambek

\footnotetext{
${ }^{1}$ For an account of how Durkheim is explicitly working within an early 'emergence' paradigm, see Sawyer (2002). I use the term 'emergence' to cover what Rappaport calls 'cybernetics;' both terms refer to how relational and organizational features of an aggregate play a causal role in system dynamics, resulting in new system capabilities and qualities. For a history of emergence thought, see Clayton (2006). For a state-of-the art articulation of emergence theory, see Deacon (2006).
} 
(2001) consider Ritual and Religion to be the most significant treatment of its subject since Elementary

Forms. Rappaport takes up themes from Durkheim's account of religion with much better and more explicit emergence categories, analyzing religious communities from the perspective of a 'cybernetics of the holy.' I argue in this paper that Rappaport misses an opportunity to integrate more tightly his account of the ritual dynamics connecting religious cognitive content, the psyches of ritual participants, and the adaptive form of religious community sociality. I want to correct this lacuna in his theory, offering a fuller account of the formal, organizational dynamics of a religious community.

\section{Rappaport's theory of religion}

Though he never offers an explicit definition of religion in Ritual and Religion, Rappaport seems to think there are two defining characteristics of religious communities:

1. Religious communities foster alternative forms of consciousness in at least some individual participants that motivates their enthusiastic participation.

2. Religious community social dynamics are adaptive and self-regulating, explaining the unprecedented persistence of religious traditions across time, geography, ethnic location, and cultural change.

Rappaport argues that the first of these is a result of the communitas caused by ritual participation, and that the second of these is the outcome of the way ritual participation, combined with the peculiar structure of religious cognitive content, affects sociality. What Rappaport fails to notice is that there are also profound effects of ritual participation involving religious cognitive content on the psychic life of individuals, which means he misses an opportunity to demonstrate how the same formal feature grounds the psychic and the social. By explicitly theorizing the psychic effects of ritualized divine concepts, we will be able to see the way divine concepts, individual experience, and an adaptive, selfregulating social organization are coordinated into a mutually reinforcing set. Specifically, we will see that ritualizing divine concepts does three things: it invites intense and meaningful reconstructions of personal identity according to paradigmatic examples; it acts as a form of encoded social memory by 
organizing human relationship according to a 'spiritual map'; and it provides the cognitive framework that makes religious community organization robust, adaptive, and reproductive.

My task in this paper will be to first identify what Rappaport means by divine concepts, and what he means by ritual. Next, I will examine how he believes these combine to secure the adaptive and self-regulating form of religious community dynamics. Then, I will investigate how Rappaport (incorrectly) thinks ritual produces alternative forms of consciousness, and offer an alternative account based on the impact of ritualized divine concepts on the psyches of ritual participants. Lastly, I will theorize how divine concepts act as a form of encoded social memory, organizing human social relationships according to a 'spiritual map.'

\section{A. Divine concepts}

Rappaport argues that a very special set of concepts are central to the coordination of public sociality that characterizes religious communities. He uses several different terms to characterize this most central feature - canonical messages, liturgical orders, logoi, ultimate sacred postulates, cosmological axioms, dominant symbols, material metaphors. Some of these are distinguishable from others, while some seem to be synonymous terms. I will distinguish the two most important, Ultimate Sacred Postulates and Dominant Symbols, ${ }^{2}$ and suggest that these two together compose what we typically

\footnotetext{
${ }^{2}$ More often than not, Rappaport uses the term 'Cosmological Axioms' to refer to the complement to Ultimate Sacred Postulates; I have chosen to use 'Dominant Symbols' because 1) he uses it at times, 2) other theorists of religion have used the term in a manner similar to the way Rappaport uses 'Cosmological Axioms,' and 3) 'Dominant Symbols' calls attention to their metaphorical quality better than does 'Cosmological Axioms,' which (I think, misleadingly) draws attention to their discursive quality.
} 
mean by 'divine concepts' such as Yahweh, the Tao, and Qi. ${ }^{3}$ According to Rappaport, divine concepts identify and describe the real but abstract metaphysical world posited to ground human experience. Divine concepts define the fundamental character of the cosmos; their objects are not determinate things here and now, but rather foundational principles that stand outside of time and space. Their significata are "spiritual, conceptual, or abstract," and they necessarily require symbols to be represented (Rappaport 1999: 278, 54).

For Rappaport, all divine concepts such as Yahweh, the Tao, and Qi can be viewed as having two aspects. One aspect is the specific, tangible, characteristic events and examples that make known the divine, and that contribute to the complex of meanings that make up a divine name. 'Yahweh,' for example, is a name for an unseen agency with certain characteristic concerns, who has a history of interaction with a particular people, through some particularly important events. Those concerns, those events, and the interpreted history of that interaction represent what Rappaport calls the Dominant Symbols (DSs) that describe and characterize the divine. The second aspect of divine concepts, what Rappaport calls the Ultimate Sacred Postulates (USPs), names the abstract and nonmaterial cause posited for the tangible events and examples that make up Dominant Symbols. This abstract and ideal cause transcends any and all particular tangible events or examples of the divine; any event or example deemed a manifestation of Yahweh is not Yahweh in toto, but rather a particular manifestation of

\footnotetext{
${ }^{3}$ More technically, I will follow the conclusion of the Comparative Religious Ideas Project suggesting that religious cognitive content falls along a spectrum between two 'poles.' One pole views religious content as "ontological ultimates," while the other views such content as "ultimate ways." Thus, the general term 'divine concepts' and the correlative phrases 'the divine' and 'divine beings and ways' will be used to cover both of these poles. See Neville and Wildman (2001: 209). For a fuller explication of this project's conclusions, see Neville (2001).
} 
Yahweh, who remains 'in another realm.' ${ }^{4}$ It is this ideal, abstract and nonmaterial cause that Rappaport claims is the USP of a divine concept.

Rappaport's point is that conceptualizing the divine involves reifying a purported abstract and ideal cause of a type of event, quality, experience, or natural phenomena, as distinct from merely acknowledging the existence of particular token events, qualities, experiences, or natural phenomena. As an analogy, consider that some mathematicians of a Neo-Pythagorean persuasion view 'threeness' as an abstract quality that exists in a Platonic realm of ideal forms that cannot itself be pointed to, though one can point to any number of specific examples of three things. To call any token of three things an example of 'threeness' is not to say that 'these three things here' exhaust or are themselves 'threeness,' which exists over and above any particular manifestation of three things. Similarly, to claim 'this fire is divine, a manifestation of Agni' is not to say that this particular fire, here-and-now, exhausts what is meant by 'Agni,' but rather that it partakes of the divine fire Agni. If the meaning of Agni was exhausted by this fire, here-and-now, 'Agni' would simply be the name for 'this fire, here-and-now.' USPs name the 'type' that grounds what any particular token partakes of but does not exhaust.

Without specific Dominant Symbols, the reified, abstract aspect of a USP would have no meaning at all. 'Yahweh,' without an account of Yahweh's agency, concerns, and dealings with a particular people, is a nonsense word, signifying nothing. USPs are, strictly speaking, 'empty' because

\footnotetext{
${ }^{4}$ This phrase, biased as it is by Western metaphysical assumptions about 'reality,' is extendable in the direction of Eastern metaphysical assumptions. That is, whether the abstract ideal realm is viewed statically as a kind of 'Being' that exists some where, transcending the world of the mundane, as it is in most western metaphysics, or viewed dynamically as a kind of 'Way' that manifests immanently in some whens, transcending the world of the mundane, the ideal realm is held to be distinguishable from the normal beings and processes of life. For a fuller explication of this, see Cassell (2012, sec. 6.2).
} 
they name that aspect of a divine concept that is 'not used up' by particular manifestations; there is something claimed to be left over besides any and all particular manifestations of the divine.

Given the close connection between abstract types like 'threeness' and divine concepts like 'Yahweh,' how does a divine concept differ from an abstract type? Abstract concepts are only meant to represent limited, local manifestations of the cosmos. Rappaport says that divine concepts are types that represent the character of the cosmos as a whole in its most basic, foundational moments, and are meant to govern nature, the personal, and the social in their totality, in their unity. Nature as a whole, as well as human experience and social life, should demonstrate the truth of divine concepts. When this happens, it is celebrated by religious communities, but when nature, human experience, or social life fails to indicate its 'ground of being,' the religious 'work' of ritual and religious experience is called on to address the failure.

To summarize the distinction between USPs and DSs and how together they represent divine concepts, Dominant Symbols reveal and characterize the divine nature or way and its effects, the Ultimate Sacred Postulates name and point to the unseen divinity (1999: 272-3). During a Catholic Mass a divinity is addressed that can neither be seen, heard, touched, smelled, or addressed physically; in the ritual, however, holy places, holy sounds, holy music, and holy words and addresses take the place of this absence (Murphy 1979: 326). The divinity is named by USPs, the divinity is accessed through DSs.

\section{B. The ritual form}

Having discussed Rappaport's characterization of divine concepts, I now turn to his understanding of ritual. Ritual, for Rappaport, gives a form or structure to human behavior, and sets apart certain ideas and content as special. Ritual is "the performance of more or less invariant sequences of formal acts and utterances not entirely encoded by the performers" (Rappaport 1999: 24). In ritual, a pattern of relations between individuals is established distinguishable from the individuals themselves; individuals may come and go, but the form of the ritual they participate in remains the same. Ritual acts as a 
'backbone,' a permanent and authoritative procedure by which individuals engage ideas and each other over time in a guided, structured way.

The form of ritual is distinct from the content of ritual, and communicates something about that content that cannot be communicated in any other way. The performance of ritual 'frames' whatever symbolic content is contained within it. That frame communicates certainty, importance, specialness, and public acceptance, regardless of the private beliefs of an individual. Acceptance of ritualized content protects that content and makes it resistant to change; ritual establishes what is 'center' and what is 'periphery' in cultural systems. Depending on what symbolic content is made central, social structures of great longevity can result.

\section{Metaperformativity}

'Metaperformativity' is Rappaport's term for the outcome of connecting divine concepts with the formal entailments of ritual. Rappaport explicitly equates metaperformativity with Austin's concept of 'performative utterances' (Austin 1962; 1970), but they are performatives of a peculiar type. They not only bring conventional states of affairs into being, as performative utterances do ('the bar is closed;' 'I now pronounce you husband and wife'), but they establish the understandings defining states of affairs, as well as the character of the cosmos in which those affairs have their place. Rappaport argues that the performance of ritual involving divine concepts has a least three characteristic outcomes. First, ritual participants are inherently stating their acceptance of divine concepts by their participation in ritual. As Paul (2002: 524) notes in his review of Ritual, to perform a ritual is to indicate both to oneself and to others acceptance of that order, obligating the performer to the central message of the ritual. Second, through participation in ritual, a performer becomes fused with the very message he or she both transmits and receives. Performance of ritual is to 'breathe reality' into an unseen metaphysical order by demonstrating it as active and authoritative. Ultimate Sacred Postulates are "not merely claimed, postulated or advanced, but...constituted by the performativeness intrinsic to liturgical orders 
themselves." The truth of divine concepts "is established in the mode or manner of their expression." Within human social systems, their truth is ontological rather than epistemological: "If no one any longer recited the Shema," Rappaport writes, "'The Lord Our God the Lord is One' would cease to be a social fact, whatever the supernatural case may be" (Rappaport 1999: 283, 405, 118-9, 278-99, 19, 295). Third, the metaphysical order presented and accepted through ritual performance is indicated to be without alternative, and changeless. Through its invariance, ritual performance declares what is true; it does not question or offer alternatives to what it presents. Performance of ritual implies the singular acceptance of what is presented, offering a meta-message for what it encodes: "This is the Word" (1999: 286, 345, 166). Metaperformativity establishes the collective acceptance of fundamental cosmological postulates such that orderly social life can proceed as if there is absolute truth (Paul 2002: 524). Metaperformativity, in sum, means that what is claimed in ritual is demonstrated through ritual; performance of ritual enacts within human sociality the society-organizing truth that it claims is true. D. How metaperformativity supports the adaptive and self-regulating social form of religious communities

Perhaps the central theme of Rappaport's book is the robust, adaptive effect that metaperformativity has on social organization. The survival of a ritually-organized community depends on its ability to persist by protecting its identity on the one hand, while simultaneously being able to adapt to different material and cultural situations on the other. How does the ritualization of divine concepts support these seemingly conflicting demands? The key is noting the hierarchical nature of divine concepts.

Rappaport believes that ritual establishes Ultimate Sacred Postulates at the unchanging center of the conceptual structure of a religious community, surrounded by 'protective belts' of layers of concepts and principles that are more changeable. This form of organization allows a religious community to respond "homeostatically to perturbations by modifying their symbol systems in order to maintain the truth value of certain fundamental propositions" (Parmentier 2003: 162). The first such 
protective belt is the Dominant Symbols we have discussed; DSs rarely change in the course of the evolution of religious communities, although they can occasionally be added to or subtracted from. At the next layer are things like ritual prescriptions, taboos, commandments - rules for living in accordance with USPs as made known through DSs. Even more peripherally are sanctified forms of sociality like political agreements, compacts, and rules for economic exchange that ultimately rely for their justification on USPs in some manner; and even beyond that are sanctified tokens such as vows, pledges, promises, etc. (Rappaport 1999: 427).

Rappaport notices that propositions closer to the center of this hierarchy of sacredness are general and important, and as we move towards the periphery they become more specific and pragmatic. For example, Dominant Symbols are mere metaphors; at best, they only suggest which more-concrete commandments, ritual prescriptions, taboos and such will be authorized. At the center, most vague of all, stand Ultimate Sacred Postulates, which do not refer to anything in this world, by definition. USPs are nonmaterial and without character in and of themselves. Rappaport notes that the 'emptiness' of meaningful content at the center of a religious community is crucial to the community's adaptability. "Ultimate Sacred Postulates do not in themselves specify particular social or material goals, or the proper means for fulfilling them. Specifying nothing they can apparently sanctify anything" (1999: 427-8). Having an empty placeholder, like the numeral '0,' at the center of a religious community's conceptual organization insures its longevity in the face of variable conditions. Like a biological organism, a religious community can adapt to different niches and changing conditions in the larger cultural and social environment; the survival of the religious community as such is the central effect of its organizational form (1999: 424).

\section{E. How ritual formality causes alternate states of consciousness connected to divine concepts} Having explained divine concepts, ritual, the outcome of ritualizing divine concepts ('metaperformativity'), and how metaperformativity supports an adaptive and self-regulating social 
system, I now need to explain how Rappaport thinks ritual fosters alternative forms of consciousness in at least some individual participants, motivating their enthusiastic participation in religious community life. Rappaport argues that the ritual entrainment of a group causes non-rational numinous experience, which validates by association the ideational content of ritual (1999: 373, 398-9).

Rappaport suggests the highly coordinated social behavior found in ritual dissolves normal consciousness into a kind of shared consciousness wherein the larger entity of the social unit becomes dominant in consciousness. The self and the other become blurred in communitarian ritual. He thinks the 'revelation of hidden oneness' is the core meaning of communitarian ritual; highly entrained group behavior is the origin of highest-order meaning, which is a function of participation. The meaningfulness found in highly coordinated sociality makes divine concepts feel true by simple association, at least according to the explicit account given in Ritual and Religion. Rappaport writes that divine concepts "seem to partake" of the meaningfulness and authority of the profound experience of ritually-induced communitas. He admits that it is "logically unsound" to draw conclusions as to the truth of divine concepts from this association. But since it "does not trouble the faithful," it shouldn't trouble us (1999: $403-5,225-6,380-1)$.

This, in my opinion, is not only incorrect, but represents a missed opportunity to bind together more tightly his account of adaptive sociality with his account of alternate states of consciousness in the individual. Implicit in his theory is an alternative account of the way metaperformativity invites alternate states of consciousness that is more relevant and useful to his cybernetic theory of religion, which I will take up in a moment. Notice, however, that even with its shortcomings, his account allows Rappaport to argue that ritual links together the individual and the social group in a way that is mutually beneficial to both - a central idea behind cybernetics and emergence theory. Because ritual performance, for Rappaport, generates numinous experience, and numinous experience generates commitment to an adaptive hierarchy of conceptions crowned by USPs, ritual connects both individual 
experience and adaptive sociality. The individual finds USPs meaningful, and the social organization founded in ritual is robust, adaptive, and long-lived.

Rappaport's fundamental contribution to religious studies is that he offers a profound theory as to why religious communities are the oldest, most robust and adaptive form of sociality on earth. These characteristics are entailments of ritual formality combined with divine concepts. Because ritual, when framing divine concepts, produces a type of performative utterance - what he calls a 'metaperformative' - it produces an adaptive and self-regulating system of social relations that resists change in some areas even as it changes in others. This system of social relations reproduces by communicating to individual participants in a way that has a powerful effect on the psyche. This is the core of Rappaport's theory (Robbins 2001: 594).

\section{Rappaport, revisited}

Rappaport explicitly argues the meaningfulness of USPs is borrowed from the numinous experience of ritual participation; there is nothing about divine concepts in themselves that contributes to the powerful experience found in religious ritual. This means that negative political ideology can be experienced numinously through association with communitas (e.g. the "numinousness of the Nuremberg rallies") as easily as can divine concepts (Rappaport 1999: 404). But there is something about divine concepts that makes them efficacious in promoting religious experience, and it is implicit in Rappaport's own account. That is what I want to address now. To do so, however, I first will need to get specific about what I mean by 'religious experience.'

\section{A. An alternative account of religious experience involving 'decentering'}

Scholarly understanding of 'religious experience' varies widely; ${ }^{5}$ my use of the term, for the purposes of this paper, follows Wildman's (2011) analysis of 'intense' experiences and how they are related to what neuroscientist McNamara (2009) calls 'decentering.' Wildman suggests that an adequate

\footnotetext{
${ }^{5}$ See James (1985), Proudfoot (1985), and Saver and Rabin (1997) for different takes on the subject.
} 
phenomenological analysis of religious experience actually reveals experiences that fall under several conceptual categories. He distinguishes "vivid experiences" from normal or mundane experience. Vivid experiences are "relatively unusual, typically colorful states of consciousness" that are either extremely significant or extremely strange. The border between these vivid and mundane experience is "set by our physiology in interaction with our environment, which allows certain habits to form, including expectations for what is normal, unproblematic, and deserving of no special attention." A certain subset of vivid experiences he describes as intensely, existentially significant; these 'intense' experiences are "sometimes anomalous and sometimes not, sometimes religious and sometimes not, but always...related to matters of ultimate existential concern." These intense experiences are characterized by strength of feeling, the interconnectedness of ideas, memories, and emotions, and have significant social and personal effects (Wildman 2011, 77-79, 93).

Wildman argues an important example of an intense experience is found in the neuropsychological concept of 'decentering,' which McNamara introduces to describe how religious participation may meaningfully reconstruct personal identity. A bit of background to McNamara's theory is necessary here. He argues that the evolved role of the centralized executive self is to inhibit desires and goals that are inconsistent with a single, unified consciousness and a unified set of goals. However, the executive self does not possess enough agency to bind and own all the intentional states associated with the brain. It usually does so well enough to prevent problem-states like Multiple Personality Disorder, but not well enough to prevent angst and a sense of personal failure and suffering. McNamara suggests that the problem of the divided self, as it appears to us in self-consciousness, is a fundamental problem religious communities prescribe solutions for.

McNamara explains that the sense of self is malleable; brains can and will reorganize to accommodate multiple personalities. He notes that religious narratives and practices offer interpretations and models about what is possible for the self, and define what is the self in its true 
state. The highest global standard for a self is the divine being or 'way' a religious ritual is oriented towards. Religious practices encourage the taking up of that global standard; both private religious practices and participation in public rituals promote continuous transformation of the self towards these ideals. These narratives and practices integrate material about conflict concerning the present self into a resolution of that conflict in a truer self, which is experienced as relatively conflict-free.

This sets the stage for understanding decentering, and its value and function in 'religious experience.' McNamara notes that the brain systems crucial to a sense of self are precisely those that are implicated in certain religious experiences, a subset of the kind that Wildman characterizes as 'intense. ${ }^{6}$ Thus, intense experiences in a religious context might indicate the transformation of a person's sense of self towards ideals proposed by religious concepts. The key element in this transformation is decentering. Decentering involves a temporary relaxation of central neurological control that leads ultimately to greater self-control. It puts the individual in a receptive and integrative mode, and provides the protective cognitive scaffolding necessary to promote integration of cognitive and emotional content so as to put that content into service of a newly developing self. According to McNamara, decentering occurs in four stages: some impasse occurs in the experience of the present self because of conflict or conflicting desires. It could be a sense of personal defeat or failure, or a discrepancy in self-concept when compared to reality. Following this sense of failure of self, a suspension of agency, which might be facilitated by religious practices such as fasting, asceticism, ritual performance, or drug ingestion, decouples the current self from control over executive resources. The current self is placed in a 'suppositional logical space.' Next, potential alternative selves are searched until a solution to the problem is discovered. These can come from a stock of existing identities,

\footnotetext{
${ }^{6}$ McNamara's analysis does not distinguish between the different phenomenological types of religious experience Wildman analyzes, but Wildman sees McNamara's account as being primarily about intense experiences involving existential ultimacy. See discussion in Wildman (2011, 77-94).
} 
narratives of others, mythology, history, fiction, or dreams. In a religious context, the ideal self can be a deity or other supernatural agent, made particularly salient in a religious ritual. Finally, the old self is integrated into the new self via narrative devices. Importantly, decentering does not occur in working memory; it is not merely 'trying on a new self.' It can be a conscious experience, but it is not something initiated by the actor; rather, it is experienced as something that happens to a person when the current self is suppressed in some way, and guidelines for alternative selves are ready at hand to be taken up.

So McNamara's proposal offers us a way for understanding how it is that the Balinese, for example, should have such profound 'direct encounters' with divine presences like 'Rangda,' as Geertz (1973) recounts, and the Maring should have such profound experiences of 'Smoke Woman,' as Rappaport recounts. These represent decentering experiences where possession by a divine agent is expected and desired. But is there anything in Rappaport's theory that would explain why religious community participants, above others, would expect, invite, and value such experiences?

\section{B. How metaperformativity facilitates decentering}

One of Rappaport's fundamental insights is that to participate in a ritual is to participate in a performative involving an implied 'speaker' or 'revealer' of the ritual. To participate in a ritual is to perform invariant sequences of acts and utterances that the performer did not encode and that the performer does not have the authority to change. "The very invariance of ritual proposes...an agent to whom the efficacy of performativeness intrinsic to ritual's language can be attributed" (Rappaport 1999: 398). Now, in the case of ritual in service to the social contract, such as a presidential swearing-in ceremony, the implied speaker of the ritual is 'us,' all who adhere to the contract and from whom the authority of the contract ultimately flows. However, when ritual is combined with divine concepts that specifies an unseen, immaterial divine being or way, the proposed 'speaker' of the ritual is named, described, and held to be different than the group who is performing the ritual. Through metaperformativity, the identity, reality, and authority of an extraordinary speaker is implicitly claimed 
(1999: 303). ${ }^{7}$ Notice how the presence of Ultimate Sacred Postulates is responsible for this. ${ }^{8}$ USPs like 'Yahweh' and the 'Tao' are placeholders for non-material causes held to govern material/energetic/human existence. Since USPs are nonmaterial by definition, metaperformativity implies nonmaterial beings and ways are the extraordinary speakers of ritual. Through ritual, an abstract, ideal cause is identified that theoretically should be ultimately meaningful to human life. Metaperformativity also implies - and this is the critical point - that these non-material beings and ways have been accepted as real by the ritual participant. The act of participating in ritual embodies and demonstrates the truth of the divine's reality, as the divine 'speaks through' the ritual participant, being enlivened by the participant's very practice. Decentering is implied in the very act of ritual participation. Thus, what Rappaport missed in his account of religious experience is a possibility implied by his own theory: in ritual metaperformativity, normal selfhood is suppressed, and a door opened for alternative forms of selfhood to be experienced and lived. The presence of USPs in metaperformative ritual invites religious experience in the form of decentering.

Notices that divine concepts do not merely imply that some non-material, extraordinary speaker is causally active in ritual; they imply some specific extraordinary speaker is active. This is implied not in the USPs themselves, but in the Dominant Symbols associated with the USPs. Divine concepts are made up of both abstract and meaningless USPs and concrete and meaningful Dominant Symbols. With the addition of Dominant Symbols, the nature of the divine being or way is established, not just the divine's existence; the subject of the USP (the Lord, the Tao) is authoritatively characterized. For example, what is 'announced' in certain Jewish rituals are not just USPs such as the Yahweh's name, but a plethora of Dominant Symbols connected to the USP such as the Exodus from Egypt and the giving of the Law,

\footnotetext{
${ }^{7}$ Even impersonal visions of the divine can 'speak' through ritual.

${ }^{8}$ These facts about the cognitive implication of divine concepts in the next two paragraphs were anticipated by Proudfoot (1985).
} 
establishing the circumstances, reasons, and terms of the Lord's relationship to Israel. For the Confucian community, Confucius' acts of deference in Book 10 of the Analects serves to capture the key elements of Qi, suggesting how "harmony that is achieved through patterns of deference" allows one to become "a co-creator of cosmic proportions in nurturing the processes of heaven and earth" (Ames 2003: 170). The important point is that divine concepts delimit specific possibilities for divine manifestations that can potentially be experienced in the right circumstances. To have an experience of Yahweh or Qi is dependent on having a catalog of appropriate experiences that can be considered legitimate tokens of Yahweh, or Qi. For one to experience a miraculous healing from God means that one's concept of God includes the possibility of miraculous healings. And if decentering is invited, it is decentering involving a very specific ideal type of the self that is to be taken up. Divine concepts can bias one towards a posture in life that looks for, expects, and facilitates such experiences. ${ }^{9}$

To summarize, in every ritual act involving divine concepts, there is an implicit set of claims being made by participants. First, that the divine exists, and exists in certain ways, with certain specific characteristics. Second, that one is accepting the authority of the divine, and embodying the divine through ritual practice. And third, that one's normal self is submitting to an extraordinary causal influence. Religious ritual invites the suppression of normal selfhood, and decentering in a particular direction. Metaperformativity implies the divine may be accessed through specific, intense experiences of religious transformation. This is why, in exceptional circumstances, religious communities that do not explicitly invite decentering processes can be potent locations from which such experiences can flow. This fact was registered by Viktor Frankl, a psychologist who survived the Auschwitz concentration camp. He noted that the extreme conditions forced upon Jewish prisoners there released profound

\footnotetext{
${ }^{9}$ This is not to claim that such experiences are purely interpretation, as Proudfoot argues; some causal linkage between the divine as conceived and the experience might be considered as a result of some sort of collective, shared subjective experience.
} 
manifestations of Jewish piety in the form of charismatic experiences, lying latent in the Jewish traditional religion forming the background of the secular Jews brought to Auschwitz. This religious training provided the scaffolding for meaningful, anomalous interaction with the divine, as conceived through Judaism (Frankl 1963). ${ }^{10}$

${ }^{10}$ This is an important point that suggests a response to a potential criticism of this view. Boyer (2001) argues that overemphasizing the 'spectacular' when considering religion gives the impression that there is a 'pure' form of religion that includes special kinds of experiences that exceptional people experience, and that the masses degrade. Boyer's take is that the exceptional experience is merely an outlying form of mundane religion that is not much more than a conglomeration of biases resulting from our evolutionary history (Boyer 2001, see especially 307-310). In response, note it is the outlier that is held up as the paradigmatic religious practitioner in most religious communities, and in exceptional circumstances such as Nazi concentration camps, the outlier might be held up as the norm. The 'heroes' of religion - those that found movements, re-inspire old movements, and are deemed as especially 'blessed' - are those that in some way or another are held to be particularly close to or possessed by the divine. Saints and prophets, as well as Christs, Sages, and Bodhisattvas, are those whose exemplary embodiment or channeling of the unseen divine set the 'plumb line' for everyone else. What inspires and (re)produces the 'religious life' is the way ritual makes divine concepts present, alive, and true for participants, and this, I claim, involves decentering at some level. Second, and perhaps explaining the first point, decentering can be experienced as something unusual, unfamiliar, and unexpected, or as "familiar and perhaps highly ritualized and deliberately cultivated" (Wildman 2011: 88). I suggest that when decentering is experienced anomalously, the conscious mind is strongly displaced, translating into more spectacular manifestations in line with McNamara's account. When experienced in familiar and deliberately cultivated ways, decentering never completely or even primarily displaces the conscious 
The important contribution of non-concrete, abstract USPs to the decentering process is what they deny, what they refuse, and thus what they make room for. Metaperformativity involving divine concepts creates a 'specified absence' in the psyches of ritual participants. ${ }^{11} \mathrm{It}$ is an absence because the ritual participant is submitting to an Ultimate Sacred Postulate as an extraordinary, non-material causal influence; it is specified because specific Dominant Symbols delimit the types of possible experiences one might have of them. I suggest this alternative explanation of religious experience is much more promising as an account of 'Rangda' and 'Smoke Woman' acting as presences to their respective communities than is mere association of these divine concepts with ritual communitas. Rappaport acknowledges that metaperformativity is at the heart of religious community's adaptive, cybernetic organization, but he doesn't recognize that it might also be the source of religious experience.

\section{The connection of the psychic to the social via decentering}

What I have argued so far is that if we follow this Rappaport-inspired, alternative vision of religious experience, ritual, combined with the 'specified absence' of divine concepts, produces both the adaptive organization of the community, and the psychic experience of individuals concerning unseen causes. What still needs to be clarified is my claim that ritualized divine concepts act as a form of encoded social memory, organizing human relationship according to a 'spiritual map,' and that this accounts for the synergistic relationships coordinating divine concepts, individual experience, and religious sociality in a mutually reinforcing set. Wikstrom (1990) suggests religious communities connect four things: individual psychic motives, religious myths that somehow touch these psychic needs, socio-cultural

mind. Spectacular cases draw attention to the 'activity of the divine,' which is why they are held up as exemplars, but the 'work' of decentering takes place even in less spectacular cases.

${ }^{11}$ The term is Deacon's (2006). There is a strong kinship between what Deacon describes as a 'teleodynamic system' and Rappaport's description of a religious community. 
realities, and a kind of 'play' of religious imagination. He suggests the play of religious imagination involves the mediation of a special reality-map consisting of an existentially relevant frame of interpretation pointing to a "cosmic Thou." Others have similarly argued that religious content can act as an encoded reality-map of some sort. Boddy has argued that religious statements are one step removed from normal statements about societies; they are "coded moral and political acts...derived from thinking about one's relationships to others by thinking through the Other" $(1994: 423$, italics mine). Geerts notes that divine concepts don't directly refer to the community; they provide (quoting Turner), "a set of structures of thought and feeling" about the relationship between the living and the supernatural realm (Turner 1974:6; Geerts 1990:22). And Gardner notes that participants in rituals are not looking directly to produce conventional states of affairs with respect to sociality, but rather, to influence supernatural beings (1983:347-50). I suggest this encoding, this 'play' of religious imagination involving the mediation of a special reality-map, is the direct result of metaperformativity's effect on individual psyches. Individual self-narratives and group narratives are linked by a mediating factor: the intense, transforming alternative experiences guided and biased by a particular interpretive grid concerning the divine. The divine as experienced is a critical component systematically linking individual and group.

When ritual participants gather together in submission to the same divine concepts, normal expectations for sociality are suppressed, and the potential increases for persons experiencing decentering to interact with each other based on the shared terms defined by Dominant Symbols. This changes the character of interactions between ritual participants, as each makes room for the divine to be expressed. Even spectacular manifestations of the divine may occur as all are coordinated by the organizing potency of this specified absence - like spokes of a wheel coordinated by the hole of a wheel's hub. The decentering processes, which divine concepts guide and bias in ritual, act as a system of exchange connecting individuals and others in a group defined theologically. For example, when 
individual Native Americans pursue and experience animal 'spirit guides' in their vision quests, these experiences bond the individual to others in the religious community according to the relations between the various, theologically-described spirit guides themselves, not by the natural relations obtaining between the community. Each individual's experience of religious decentering confirms the community's story of ultimate reality, even as it contributes a new strand and a new potential vector for that story to grow and develop in open-ended ways. The community's future is guided by the terms and possibilities inherent in the theological vision of ultimate reality, and the way those possibilities have been taken up in individual experience.

I say that religious experiences act as an encoded bridge, because the connection between individual and group is not direct, as it is in the relations between individuals and groups that are not mediated by decentering and intense experiences. Participants in a nation-state, for example, view their individual and corporate identifies as a result of concepts and roles that are pragmatically and specifically about sociality and the connection of the individual to the group. Constitutions, such as the US constitution (which opens with an explicit performative utterance concerning the reasons and terms for the relations between the individual and the group: 'We the people, in order to form a more perfect union...do ordain and establish this Constitution'), give direct terms and reasons for the political relationships between people. Religious initiations, confirmations, and private decentering experiences, on the other hand, depend not upon direct, unmediated terms to connect people to each other, but upon terms locating the individual in relationship to the divine, which in turn locates the individual to the community. Many individuals become coordinated with each other through their shared commitment to the divine encountered by their mutual submission via ritual metaperformativity, and the history of generations of people who have participated in this 'metaperformance' creates a shared narrative that constrains each individual's experience of the divine. The efficacy and force of the 
connection between those participants in religious ritual depends upon the experience of the divine, since otherwise the connection is based on something non-existent.

It is important to note the synergistic effect of ritual and divine beliefs on individuals and groups: it is this synergy that gives the ongoing dynamics of a religious community its systemic and emergent character. As ritualized divine beliefs are made individually meaningful in decentering, community ritual dynamics are reinforced and a group metaphysical order is established; as community dynamics are reinforced and a group metaphysical order is established, individuals will be invited to access transformative decentering experiences. Each provides the condition for the other's continued existence.

To summarize my overall argument, the metapeformative establishment of divine concepts links the psychic and the social by simultaneously creating a) a robust, conservative, but adaptive social order, and b) a creative, meaningful, and experientially potent 'psychic order.' Both are facilitated by a decentering process that transforms the self in the image of divine concepts, and biases social forms towards cooperation. Religious communities, then, have a general form and a particular manifestation. The general form of the community is given by ritual that takes Ultimate Sacred Postulates and makes them authoritative and embodied, which helps suppress 'selfhood,' invite decentering, and encode social forms. The particular form of the community is given by the effect of its particular Dominant Symbols on decentering, and thus on sociality. It is the general form which allows us to entertain the category religious community as distinct from other forms of social organization. It is the particular form, the content-biased religious community, which gives religious communities their unique flavor, as well as their ability to adapt and to be differentially successful in reproducing themselves over time and cultural change.

D. Haitian example 
Perhaps the best example I have found in the anthropological literature analyzing a religious community in terms that suggest this revision of Rappaport's theory is Lowenthal's (1978) analysis of a Haitian voodoo service (sèvis). Against functional explanations of religious participation prevalent in some approaches to religious studies, he suggests we need to notice the nature of the rewards motivating individual participation. Lowenthal analyzes Voodoo, known for its practice of spirit possession, in terms of the relationship between religious belief, sociology, and individual psychic experience. He notes what is definitive of spirit possession (a decentering experience) is its presence in collective performances (a ritual and social feature) and its origin in a belief in spirits (divine concepts). Together, these three influence both the psychic organization of individuals, and the social organization of aggregates. This analysis makes for a highly instructive account of what I describe as metaperformativity.

In what follows I will trace key moments in his account almost word for word, paraphrasing slightly and changing the order for clarity:

A sèvis [ritual performance] is structured, organized, and experienced in relationship to two things - basic theological tenets concerning the Iwa (ancestor spirits), and a particular aesthetic principle governing collective performance. The aesthetic and performative feature of a sèvis is tied integrally to its theological and devotional ends. The folk theory of possession is responsible. The Iwa themselves know how they want to be honored, and assert themselves in services to secure their desires. This is why possession is central to the sèvis. To induce possession is the goal, as it demonstrates the pleasure of the lwa at the sèvis. During sèvis, participants are in the presence of supernatural beings; they are natural and real, the dance itself demonstrating how real they are. The "concept of possession and a principle of performance together constitute the essential features of the cultural context within which each sèvis unfolds" (1978: 410, 402-3, 405, 411). 
A 'hot' sèvis is an involved and enthusiastic service, when the happiness of people and the happiness of the Iwa are obviously manifest. A 'hot' sèvis is not just one that has been effective at bringing on trance, however. Rather, a 'hot' sèvis "helps to create a subjective reality for the sèvite in which the essence of worship comes to be participation in the collective creation of song and dance." For those unpossessed, dancing is not dancing for the /wa, but dancing with the /wa - they are sharing in the act of aesthetic creation with the gods themselves, making it "perhaps the ultimate satisfaction of voodoo worship...no performances equal in intensity, enthusiasm, and involvement those which include the Iwa as participants" (1978: 404, 405, 407).

"Haitian aesthetic sensibilities are closely tied to the notion of full participation in the act of creation, rather than to passive contemplation or appreciation." A sèvis involves individual creativity and collective participation. There is a holistic, social component - implying the presence of both human and spiritual persons - that makes the individual dances meaningful in a way it wouldn't be otherwise $(1978: 407,409,399)$.

The sèvis is a ritual performance that orders the relationship of humans and spirits, as well as says what form of organization and tone of interpersonal relations and cooperation matters. The "theological and experiential significance of worship within this religious system emerge from the ritual process which successfully articulates this set of culturally patterned expectations with a particular mode of collective participation" (1978: 410, 398; emphasis mine). In Lowenthal's account, notice how the Iwa - non-physical, spiritual beings - organize both individual psychic experiences involving decentering, and a social form biased by the particular tone of voodoo Dominant Symbols. Individual Haitians don't gather together for the sake of sociality; they gather together to experience the Iwa, whose presence at a sèvis provides an experience of profound 
aesthetic harmonization of individual, group, and the divine. Dominant Symbols include the aesthetics of dancing with the gods, and the personal characteristics of the Iwa as given by voodoo.

The Haitian sèvis is organized around a 'specified absence' created by ritually-authorized divine concepts. The metaperformativity of the sèvis creates the expectation of specific alternate states of consciousness, guides them, and makes gathering ritually an attractive and valuable fact of Haitian life due to the collective experience of many individuals. The sèvis will continue to organize Haitian life as long as it has this value, adapting to changes in custom, culture, people groups, and geographical location as needed.

\section{Summary}

Religious cognitive content represents a 'specified absence' where both the hidden and manifest characteristics of the divine are brought together. Religious beliefs always involve reference to 'beings' or 'ways' considered as abstract idealizations of paradigmatic examples taken from common human experience, and meant to characterize causal agencies within the natural and human cosmoses. When made authoritative to a community of ritual participants through a process Rappaport calls metaperformativity, religious beliefs have three important effects on individuals and groups. First, they create the conditions that suggest the unseen divine is an active, specified causal influence, and that one is accepting both the authority of the divine and submitting oneself to the divine, through embodying the divine in ritual. This implies - and may invite - the suppression of normal selfhood, and a psychic experience called decentering. Decentering is a neuropsychological term that captures how, in a religious context, religiously-inspired visions of the self can replace - either spectacularly or in more deliberate and mundane fashion - the 'self' of a ritual participant. The way decentering is experienced will be biased and directed by the paradigmatic examples of the divine in that community. Second, as groups gather in the name of and for the sake of the divine, the decentering experiences will act as a kind of encoded social memory, and collective room for subtle and not-so-subtle manifestations of the 
divine will be made. The 'collective effervescence' of such gatherings will reinforce and extend individual experience of the divine, and allows a history of such interactions to be narrated. Third, since the divine is ultimately 'not of this world,' it can never be exhausted by or finally limited to any material or cultural manifestation of human life; the divine can be used to support or criticize many possible sociocultural manifestation. Communities defined by their relationship to the divine have a robust, adaptive, and reproductive organizational structure, and religious communities can continue to exist across great expanses of time and cultural change. These three effects of ritually-authorized divine concepts link together individual psychic experience and social organization in a mutually-reinforcing set, where particular kinds of individual experience justify participation in the ritual group, and participation in the ritual group re-invites particular kinds of individual experience.

This view of religious communities explains both the meaningfulness of religious beliefs to individuals, as well as the central place religious beliefs occupy in religious groups. It also explains why religious communities have the abstract structure of an adaptive, self-reproducing biological organism, exhibiting the same, formal organizational structure. This, in my view, is the proper way to take Rappaport's insightful application of emergence theory to religious community life and extend it.

\section{Works Cited}

Ames, Roger. 2003. Li and the a-theistic religiousness of classical Confucianism. In Confucian Spirituality, ed. Weiming Tu and Mary Tucker, 1:165-182. New York: The Crossroad Publishing Company.

Austin, J.L. 1962. How to Do Things with Words. Oxford: Oxford University Press.

- - . 1970. Performative utterances. In Philosophical Papers of J.L. Austin, ed. James Urmson and Geoffrey Warnock. Oxford: Oxford University Press.

Boddy, Janice. 1994. Spirit possession revisited. Annual Review of Anthropology 23 (1): 407-434. Boyer, Pascal. 2001. Religion Explained. New York: Basic Books. 
Cassell, Paul. 2012. A semiotic and emergent theory of religious communities. Ph.D. Dissertation, Boston, MA: Boston University Publication No. AAT 3500313.

Clayton, Philip. 2006. Conceptual foundations of emergence theory. In The Re-emergence of Emergence, ed. Philip Clayton and Paul Davies, 1-31. Oxford: Oxford University Press.

Deacon, Terrence. 2006. Emergence. In The Re-Emergence of Emergence, ed. Philip Clayton and Paul Davies, 111-150. Oxford: Oxford University Press.

Durkheim, Emile. 1995. The Elementary Forms of Religious Life. New York: The Free Press.

Gardner, D. S. 1983. Performativity in ritual. Man 18 (2). New Series (June 1): 346-360.

Geerts, Henri. 1990. An inquiry into the meanings of ritual symbolism. In Current Studies on Rituals, ed. Hans-Gunter Heimbrock and H. Barbara Boudewijnse, 19-32. Amsterdam: Rodopi.

Geertz, Clifford. 1973. The Interpretation of Cultures. New York: Basic Books.

Hart, Keith. 1999. Forward. In Ritual and Religion in the Making of Humanity, by Roy A. Rappaport, xivxix. Cambridge: Cambridge University Press.

James, William. 1985. The Varieties of Religious Experience. Cambridge, MA: Harvard University Press.

Lambek, Michael. 2001. Rappaport on religion. In Ecology and the Sacred, ed. Ellen Messer and Michael Lambek, 244-273. Ann Arbor: The University of Michigan Press.

Lowenthal, Ira P. 1978. Ritual performance and religious experience. Journal of Anthropological Research 34 (3): 392-414.

McNamara, Patrick. 2009. The Neuroscience of Religious Experience. Cambridge: Cambridge University Press.

Murphy, Ronald SJ. 1979. A ceremonial ritual. In The Spectrum of Ritual, ed. Eugene d' Aquili, Charles Laughlin, and John McManus, 318-341. New York: Columbia University Press.

Neville, Robert. 2001. Ultimate Realities. Vol. 2. The Comparative Religious Ideas Project. Albany: State University of New York Press. 
Neville, Robert, and Wesley Wildman. 2001. On the nature of religion. In Religious Truth, ed. Robert Neville. Vol. 3. The Comparative Religious Ideas Project. Albany: State University of New York Press.

Parmentier, Richard. 2003. Ritual and religion in the making of humanity (Book review). History of Religions 43 (2): 162-164.

Paul, Robert A. 2002. The social act basic to humanity (Book review). Current Anthropology 43 (3): 524526.

Proudfoot, Wayne. 1985. Religious Experience. Berkeley, CA: University of California Press.

Rappaport, Roy A. 1999. Ritual and Religion in the Making of Humanity. Cambridge: Cambridge University Press.

Robbins, Joel. 2001. Ritual communication and linguistic ideology. Current Anthropology 42 (5): 591614.

Saver, Jeffrey, and John Rabin. 1997. The neural substrates of religious experience. The Journal of Neuropsychiatry and Clinical Neurosciences 9: 498-510.

Sawyer, Keith. 2002. Durkheim's dilemma. Sociological Theory 20 (2): 227-247.

Turner, Victor. 1974. Symbols and social experience in religious ritual. Studia Missionalia 23 (1-21).

Wikstrom, Owe. 1990. Ritual studies in the history of religions. In Current Studies on Rituals, 57-67. Amsterdam: Rodopi.

Wildman, Wesley. 2011. Religious and Spiritual Experiences. Cambridge: Cambridge University Press. 